\title{
PENGARUH KEPUASAN KERJA DALAM MEMODERASI MOTIVASI KERJA DAN PENGGAJIAN MENURUT PERSPEKTIF ISLAM TERHADAP KINERJA KARYAWAN PT BNI SYARIAH CABANG MAKASSAR
}

\author{
Irwansyah \\ Universitas Islam Negeri Alauddin Makassar \\ Jl. H.M. Yasin Limpo No.62. Romangpolong-Gowa \\ irwansyaherl@yahoo.co.id
}

\begin{abstract}
The purpose of this study was to find out effect of job satisfaction in moderating the work motivation of Islamic perspectives and payroll Islamic perspective on the performance of employees of PT BNI Syariah Makassar Branch. The population in this study were all employees of PT BNI Syariah Makassar Branch, amounting to 67. Determination of the sample used a purposive sampling method. Data analysis used multiple linear regression analysis and regression moderating analysis with absolute difference test approach. The results showed that work motivation and payroll in an Islamic perspective had a positive effect on employee performance and job satisfaction was able to moderate the positive relationship of Islamic perspective work motivation on employee performance but was not able to moderate the Islamic payroll perspective on employee performance. The implications in this study provide input in an effort to improve the performance of employees of PT BNI Syariah Makassar Branch.
\end{abstract}

\begin{abstract}
Abstrak: Penelitian ini bertujuan untuk mengetahui pengaruh kepuasan kerja dalam memoderasi motivasi kerja perspektif Islam dan penggajian perspektif Islam terhadap kinerja karyawan PT BNI Syariah Cabang Makassar. Populasi dalam penelitian ini seluruh karyawan PT BNI Syariah Cabang Makassar yang berjumlah 67. Penetapan sampel menggunakan metode purposive sampling. Analisis data menggunakan analisis regresi linear berganda dan analisis regresi moderating dengan pendekatan uji selisih mutlak. Hasil penelitian menunjukkan motivasi kerja dan penggajian dalam perspektif Islam berpengaruh positif terhadap kinerja karyawan dan kepuasan kerja mampu memoderasi hubungan positif motivasi kerja perspektif Islam terhadap kinerja karyawan namun tidak mampu memoderasi penggajian perspektif Islam terhadap kinerja karyawan. Implikasi dalam penelitian ini memberikan masukan dalam upaya meningkatkan kinerja karyawan PT BNI Syariah Cabang Makassar.
\end{abstract}

Kata Kunci: Kepuasan Kerja, Motivasi Kerja, Penggajian, Kinerja, Perspekttif Islam

\section{PENDAHULUAN}

Setiap perusahan perbankan sangat tergantung atas jasa agen atau marketing penjualan dalam mempromosikan produk layanan yang dimiliki, sehingga perusahaan telah menganggap agen ataupun marketing adalah asset penting yang harus dipertahankan dan dikembangkan agar perusahaannya dapat bertahan dan tidak terkalahkan oleh perusahaan perbankan lain di Indonesia. Agen maupun marketing memiliki banyak tantangan yang besar, mereka harus mampu menjual 
produk layanan yang ditawarkan sekaligus menjaga kepercayan nasabah agar tidak mengalami kekecewaan dan beralih pada perusahaan perbankan lain. Maka dari itu seorang agen atau marketing membutuhkan kemampuan atau bakat serta kinerja yang baik, yang menempatkan mereka sebagai mitra yang baik bagi para nasabah maupun perusahaan. Kinerja yang baik mengandung arti terjadinya peningkatan efisiensi, efektivitas, atau kualitas yang lebih tinggi dari penyelesaian serangkaian tugas yang dibebankan kepada seorang karyawan dalam suatu organisasi atau perusahaan (Murty dan Hudiwinarsih, 2016).

Terkait persoalan kinerja karyawan hubungannya dengan motivasi Islam, terdapat banyak hal yang dapat memotivasi seseorang yang bekerja sebagai karyawan di BNI Syariah diantaranya dapat berupa mendapatkan bonus saat target terpenuhi, promosi jabatan lebih cepat, ataupun motivasi kenyamanan di bidang psikologis karena tidak melanggar syariat Islam. Motivasi adalah sesuatu yang mendorong seseorang untuk berperilaku tertentu yang membuat seseorang memulai melaksanakan dan mempertahankan kegiatan tertentu. Dengan kata lain, motivasi dianggap sebagai dorongan individu untuk melakukan tidakan karena mereka ingin melakukannya (Wijayanti dan Meftahuddin, 2016). Apabila individu termotivasi, mereka akan membuat pilihan yang positif untuk melakukan sesuatu karena dapat memuaskan keinginan mereka (Rivai, 2009:56).

Kinerja suatu perusahaan sangat ditentukan oleh kondisi dan perilaku karyawan yang dimiliki perusahaan tersebut. Fenomena yang seringkali terjadi adalah kinerja suatu perusahaan yang sudah baik dapat menurun, baik secara langsung maupun tidak, oleh berbagai perilaku karyawan yang mempunyai keinginan untuk berpindah (intentions) yang berujung pada keputusan karyawan untuk meninggalkan pekerjaannya (Toly, 2001). Dengan tingginya tingkat turnover pada perusahaan, semakin banyak menimbulkan berbagai potensi biaya, baik itu biaya pelatihan yang sudah diinvestasikan pada karyawan, tingkat kinerja yang mesti dikorbankan, maupun biaya rekrutmen dan pelatihan kembali yang berujung pada menurunnya kinerja pada perusahaan tersebut.

Selain motivasi, persoalan lain yang dapat berdampak pada kinerja karyawan di PT BNI Syariah adalah gaji yang diterima. Berdasarkan fenomena yang terjadi pada PT BNI Syariah adalah tingginya turnover karyawan sebagai akibat faktor gaji, kepuasan kerja, jenjang karir, maupun mencari pengalaman baru di tempat lain. Gaji dapat dikatakan sebagai balas jasa yang diberikan oleh perusahaan kepada tenaga kerja, karena tenaga kerja memberikan sumbangan tenaga dan pikiran demi kemajuan perusahaan guna mencapai tujuan yang telah ditetapkan baik dalam jangka pendek maupun jangka panjang (Kasenda, 2013). Gaji merupakan salah satu cara yang dapat diberikan perusahaan berupa imbalan kepada karyawan (Wijaya dan Andreani, 2015). Gaji dapat meningkatkan ataupun menurunkan kinerja karyawan. Pemberian gaji kepada karyawan perlu mendapatkan perhatian lebih oleh perusahaan.. Oleh karena itu agar dapat mempertahankan kinerja karyawan yang baik, maka sistem penggajian dibuat sedemikian rupa, sehingga karyawan yang berpotensi akan merasa dihargai dan bersedia untuk bertahan di perusahaan (Muljani, 2010). Gaji yang diberikan kepada karyawan bertujuan untuk lebih memotivasi dalam meningkatkan kinerja di perusahaan. Sistem penggajian yang baik 
yang sesuai dengan syariat Islam akan memotivasi karyawan untuk meningkatkan kinerjanya karena tidak adanya keterlambatan dan ketidaktepatan dalam proses penerimaan gaji karyawan. Selain itu, karyawan akan merasa dengan bekerja bukan hanya mendapat penghasilan dan dapat memenuhi kebutuhan, tetapi juga untuk mencari nafkah yang merupakan bagian dari ibadah (Anoraga dan Prasetyo, 2015).

Gaji merupakan motif yang didesain untuk meningkatkan motivasi kerja karyawan apabila insentif tersebut dilakukan dengan benar. Nurdiana (2011) sistem penggajian yang jelas secara psikologis akan mendorong karyawan untuk bekerja dengan baik. Disamping faktor motivasi kerja dan sistem penggajian dalam perspektif islam yang dapat mempengaruhi kinerja karyawan, kepuasan kerja juga memiliki peran yang sangat besar dalam meningkatkan kinerja karyawan (Wijayanti dan Meftahuddin, 2016). Perusahaan yang dapat bertahan dalam dunia bisnis adalah memiliki SDM yang produktif, inovatif, kreatif, selalu bersemangat dan loyal. Salah satu faktor yang mempengaruhi loyalitas karyawan adalah kepuasan kerja karyawan. Karyawan yang kepuasan kerjanya rendah akan berakibat pada penurunan kinerja perusahaan secara keseluruhan, karena karyawan menjadi motor penggerak dari perusahaan.

Berdasar pada salah satu penelitian mengatakan bahwa kepuasan kerja dapat memoderasi semua variabel kinerja diantaranya kepemimpinan, motivasi dan kepuasan gaji berpengaruh positif dan signifikan terhadap kinerja suatu karyawan (Mulyanto dan Widayati, 2010). Kondisi ini menunjukkan bahwa, aspek-aspek dalam kepuasan kerja seperti: pekerjaan yang dilakukan sangat menarik, lebih suka melaksanakan pekerjaan lain, tunjangan yang diperoleh cukup banyak, organisasi memberi gaji lebih baik daripada pesaing, serta motivasi yang tinggi diberikan oleh perusahaan. Hakekatnya adalah kepuasan kerja memberikan rasa puas untuk maju, dan mendapatkan penghargaan serta kepuasan karyawan yang sudah terpenuhi atau sesuai dengan harapan akan meningkatkan kinerja karyawan serta mencapai tujan suatu organisasi.

Berdasarkan latar belakang dan permasalahan tersebut tujuan penelitian ini untuk menganalisis pengaruh motivasi kerja dalam perspektif Islam dan penggajian dalam perspektif Islam terhadap kinerja karyawan serta pengaruh kepuasan kerja dalam memoderasi motivasi kerja dan penggajian dalam perspektif Islam terhadap kinerja karyawan.

\section{TINJAUAN TEORETIS}

\section{Theory Of Planned Behavior}

Theory of plan behavior pertama kali digunakan oleh Icek Ajzen pada tahun 1958. Theory of Planned Behavior (TPB) atau perilaku yang direncanakan menjelaskan bahwa perilaku seseorang dipengaruhi oleh faktor sikap, norma subjektif, serta kontrol keperilakuan yang dipersepsikan. Perilaku atau tindakan seseorang terjadi karena adanya niat untuk melakukan hal tersebut atau niat untuk berperilaku (Tiraada, 2013). Theory of Planned Behavior menjelaskan bahwa perilaku yang dilakukan oleh individu timbul karena adanya niat untuk berperilaku. Niat untuk melakukan perilaku (intention), merupakan komponen diri individu yang mengacu pada keinginan untuk 
melakukan perilaku tertentu (Sanyata, 2012). Teori TPB menjelaskan bahwa yang melandasi seseorang berperilaku karena adanya niat. Begitupun dengan karyawan, dalam melaksanakan tanggungjawab pekerjaannya didasari karena adanya niat untuk melakukan hal tersebut.

\section{Teori Keadilan (Equity Theory)}

Keadilan berasal dari bahasa arab " $a d l$ " yang artinya bersikap dan berlaku dalam keseimbangan. Keseimbangan meliputi keseimbangan antara hak dan kewajiban dan keserasian dengan sesama makhluk. Keadilan pada hakikatnya adalah memperlakukan seseorang atau orang lain sesuai haknya atas kewajiban yang telah di lakukan. Adapun yang menjadi hak setiap orang adalah di akui dan di perlakukan sesuai harkat dan mertabatnya yang sama derajatnya di mata Allah . Hak-hak manusia adalah hakhak yang diperlukan manusia bagi kelangsungan hidupnya di dalam masyarakat (Rangkuti, 2017). Teori keadilan yang pertama kali dikemukakan oleh Adam 1965 menjelaskan bahwa individu membandingkan rasio usaha mereka dan imbalan dengan rasio usaha dan imbalan pihak lain yang dianggap serupa (similar) (Hersusdadikawati, 2005). Teori keadilan ini didasarkan pada asumsi bahwa orang-orang dimotivasi oleh keinginan untuk diperlakukan secara adil dalam pekerjaannya. Seperti halnya sistem penggajian yan diterapkan oleh perusahaan diharapkan setiap karyawannya memiliki sistem yang adil dan tidak merugikan pihak manapun.

\section{Teori Motivasi}

Teori Expectancy yang di ungkapkan oleh Greenberg tahun 1999. Teori motivasi merupakan suatu pandangan yang dapat digunakan sebagai acuan untuk memberikan motivasi kepada orang-orang atau kelompok tertentu dalam suatu unit bisnis. Motivasi dapat menyebabkan seseorang untuk berperilaku baik, oleh karena itu motivasi karyawan yang tinggi berbanding lurus dengan kinerja perusahaan (Dhermawan dkk, 2012). Islam sebagai agama yang sempurna, sistem keimanan dan aqidah yang diyakini oleh para pemeluknya yaitu muslim, juga mengatur mengenai etos kerja, mendorong dan mengutus umatnya untuk memiliki semangat kerja dan beramal, tanpa mengeluh yang menunjukkan adanya kepuasan bagi diri sendiri (Wijaya dan Andreani, 2015). Motivasi kerja Islam sangat penting untuk meningkatkan kualitas sumber daya manusia dalam suatu perusahaan, terutama lembaga keuangan seperti bank yang berbasis Syariah. Anoraga dan Prasetyo (2015) bank syariah sangat mengandalkan sumber daya manusia sebagai tombak untuk menjalankan kegiatannya, oleh karena itu sumber daya manusia dalam suatu bank syariah wajib memiliki motivasi kerja Islam yang baik untuk menghasilkan kinerja yang memuaskan. Oleh karena itu sebaiknya para karyawan atau pekerja perlu memiliki motivasi yang dapat memberikan kepribadian yang baik dan dibenarkan oleh Islam.

\section{Motivasi Kerja Perspektif Islam}

Motivasi merupakan dorongan terhadap serangkaian proses prilaku manusia pada pencapaian tujuan (Wibowo, 2012:125). Pemberian motivasi merupakan salah 
satu tujuan agar karyawan yang diberi motivasi dapat bekerja sesuai dengan acuan kerja dan taggung jawab yang diberikan sehingga tujuan perusahaan dapat tercapai dengan baik (Murty dan Hudinarsih, 2016). Motivasi kerja Islam sangat penting untuk meningkatkan kualitas sumber daya manusia dalam perusahaan, terutama lembaga keuangan seperti bank. Bank sangat mengandalkan sumber daya manusia sebagai tombak untuk menjalankan kegiatannya, oleh karena itu sumber daya manusia dalam suatu bank wajib memiliki motivasi kerja Islam yang baik untuk menghasilkan kinerja yang memuaskan (Anoraga dan Prasetyo, 2015). Salah satu faktor pendorong seorang melakukan pekerjaannya dengan baik, karena pekerjaan tersebut adalah bagian dari ibadah.

\section{Penggajian Perspektif Islam}

Di dalam perusahaan, terdapat macam-macam sistem akuntansi dan salah satunya adalah sistem akuntansi penggajian dan pengupahan. Sistem penggajian adalah sistem yang digunakan oleh perusahaan untuk memberikan upah dan gaji kepada karyawannya atas jasa-jasa yang mereka berikan kepada perusahaan (Jiwandono dan Yaningwati, 2017). Sistem akuntansi penggajian terdiri dari dokumen yang digunakan, catatan akuntansi yang digunakan, fungsi yang terkait, dan jaringan prosedur yang membentuk sistem. Setiap dokumen serta catatan yang digunakan dalam sistem akuntansi penggajian harus dapat memberikan informasi yang akurat (Pratama dkk, 2016). Sistem penggajian yang baik yang sesuai dengan syariat Islam akan memotivasi karyawan untuk meningkatkan kinerjanya karena tidak adanya keterlambatan dan ketidaktepatan dalam proses penerimaan gaji karyawan.

\section{Kinerja Karyawan}

Kinerja adalah hasil kerja secara kualitas dan kuantitas yang dicapai oleh seseorang dalam melaksanakan tugasnya sesuai dengan tanggung jawab yang diberikan kepadanya secara efesien dan efektif penuh kesetiaan (Mangkunegara, 2002:75). Kinerja pada dasarnya adalah apa yang dilakukan atau tidak dilakukan karyawan. Kinerja karyawan adalah yang mempengaruhi seberapa banyak mereka memberi kontribusi kepada organisasi yang antara lain termasuk kuantitas output, kualitas output, jangka waktu output, kehadiran di tempat kerja, sikap kooperatif. Terkadang kinerja karyawan menurun dikarenakan kemungkinan adanya ketidaknyamanan dalam bekerja, gaji atau upah minim, motivasi dan juga ketidakpuasan dalam bekerja (Supatmi dkk, 2012).

\section{Kepuasan Kerja}

Kepuasan kerja adalah keadaan emosional yang menyenangkan atau tidak menyenangkan dimana para karyawan memandang pekerjaan mereka (Wijayanti dan Meftahuddin, 2016). Kepuasan kerja adalah keadaan emosional karyawan dimana terjadi ataupun tidak terjadi titik temu antara nilai balas jasa karyawan dari perusahaan atau organisasi dengan tingkat balas jasa yang memang diinginkan oleh karyawan yang bersangkutan (Martoyo, 2007:156). Sebab-sebab ketidakpuasan beraneka ragam seperti hasil yang diterima rendah atau dirasakan kurang cukup memadai, kondisi kerja yang kurang memuaskan, hubungan yang tidak serasi baik dengan rekan kerja maupun dengan atasan, dan pekerjaan yang kurang sesuai. 
Kepuasan kerja akan terpenuhi bila setiap orang mampu menghasilkan pekerjaan yang menarik, puas atas tantangan kerja yang dihadapi, memberikan apresiasi atas prestasi yang dihasilkan, puas mendapatkan penghargaan dan puas menjalankan tanggungjawab kerja (Juniantara dan Riana, 2015).

\section{Motivas Kerja Perspektif Islam Terhadap Kinerja Karyawan}

Kinerja karyawan adalah yang mempengaruhi seberapa banyak mereka memberi kontribusi kepada organisasi yang antara lain termasuk kuantitas output, kualitas output, jangka waktu output, kehadiran di tempat kerja, sikap kooperatif. Sering kali kinerja karyawan menurun dikarenakan kemungkinan adanya ketidaknyamanan dalam bekerja, gaji atau upah minim, kurangnya motivasi dan juga ketidakpuasan dalam bekerja (Supatmi dkk, 2012). Dalam menilai tinggi rendahnya kinerja karyawan dapat dilihat dari seberapa besar motivasi yang diberikan perusahaan kepada karyawan. Seseorang yang mempunyai motivasi yang tinggi terhadap pekerjaannya cenderung untuk melakukan pekerjaannya dengan baik dan maksimal (Murty dan Hudiwinarsih, 2016). Hal ini berarti semakin baik motivasi kerja perspektif Islam yang diberikan kepada karyawan maka akan meningkatkan semangat dan tanggung jawab dari karyawan tersebut.

H1 : Motivasi kerja perspektif Islam berpengaruh positif terhadap kinerja karyawan.

\section{Penggajian Perspektif Islam Terhadap Kinerja Karyawan}

Dalam Islam bukan semata mata merujuk kepada mencari rezeki untuk menghidupi diri dan keluarga dengan menghabiskan waktu siang maupun malam dan tak lenal lelah, tetapi kerja mencakup segala bentuk amalan atau pekerjaan yang mempunyai unsur kebaikan dan keberkahan bagi diri sendiri, keluarga, maupun masyarakat di sekitarnya (Anoraga dan Prasetyo, 2015). Seseorang cenderung bekerja dengan penuh semangat apabila kepuasan dapat diperolehnya dari pekerjaannya salah satunya itu gaji yang diterima oleh karyawan sesuai dengan kinerja yang dilakukan dan kepuasan kerja karyawan merupakan kunci pendorong moral, kedisiplinan, serta prestasi kerja karyawan dalam mendukung terwujudnya tujuan perusahaan. Kebijaksanaan kompensasi, baik besarnya, susunannya, maupun waktu pembayarannya dapat mendorong gairah kerja dan keinginan karyawan untuk mencapai prestasi kerja yang optimal sehingga membantu terwujudnya sasaran perusahaan (Suwati, 2013). Semakin baik sistem penggajian yang diterapkan oleh perusahaan maka akan menciptakan kepercayaan karyawan yang berujung pada peningkatan kinerja.

H2 : Pemggajian perspektif Islam berpengaruh positif terhadap kinerja karyawan.

\section{Kepuasan Kerja Memoderasi Motivasi Kerja Perspektif Islam Terhadap Kinerja Karyawan}

Berdasar pada salah satu penelitian mengatakan bahwa kepuasan kerja dapat memoderasi semua variabel kinerja diantaranya kepemimpinan, motivasi dan kepuasan gaji berpengaruh positif dan signifikan terhadap kinerja suatu karyawan (Mulyanto dan Widayati, 2010). Para karyawan yang memiliki motivasi yang rendah dan tidak memiliki kepuasan kerja akan sering menampilkan rasa tidak nyaman dan 
tidak senang terhadap pekerjaannya. Akibatnya kinerja mereka menjadi buruk dan tujuan perusahaan tidak akan tercapai (Jaya, 2012). Motivasi dapat berpengaruh pada peningkatan kinerja secara berkelanjutan melalui kepuasan kerja (Muljani, 2002). Menurut Koesmono (2005) menunjukkan bahwa pengaruh motivasi terhadap kinerja karyawan dimediasi oleh kepuasan kerja. Motivasi dapat menyebabkan seseorang untuk berperilaku baik, oleh karena itu motivasi karyawan yang tinggi berbanding lurus dengan kinerja perusahaan. Dengan demikian, semakin tinggi kepuasan kerja yang dirasakan seorang karyawan akan menunjukkan kinerja yang berkualitas dan kepuasan terhadap pekerjaanya secara otomatis akan memotivasi karyawan untuk meningkatkan kinerjana terhadap perusahaan.

H3 : Kepuasan Kerja memoderasi pengaruh motivasi kerja perspektif Islam terhadap kinerja karyawan.

\section{Kepuasan Kerja Memoderasi Penggajian Perspektif Islam Terhadap Kinerja Karyawan}

Dalam melaksanakan kegiatan penggajian dan pengupahan yang baik, diperlukan adanya sebuah sistem akuntansi penggajian dan pengupahan yang harus dimiliki oleh perusahaan. Pembayaran gaji dan upah oleh perusahaan kepada karyawan yang terlalu rendah berdasarkan kinerja, produktivitas, dan kontribusi terhadap yang perusaahaan, maka hal seperti ini dapat membuat karyawan tidak puas terhadap sistem penggajian dan pengupahan perusahaaan sehingga enggan mempertahankan kinerja, produktivitas, kontribusinya yang baik untuk perusahaan (Pratama dkk 2016). Penerapan sistem akuntansi penggajian dan pengupahan yang baik akan meningkatkan kinerja karyawan dengan baik pula. Apabila sistem penggajian yang diterapkan oleh perusahaan sudah sesuai dengan standar, maka karyawan merasa puas terhadap pekerjaannya cenderung akan melakukan pekerjaannya dengan penuh semangat untuk mencapai tujuan suatu organisasi (Murty dan Srimulyani, 2013).

H4 : Syariate Engagement memoderasi pengaruh salary terhadap turnover intention karyawan.

\section{METODE PENELITIAN}

Penelitian ini dilaksanakan di PT BNI Syariah Cabang Makassar Jl. Sam Ratulangi No. 140, Makassar Sulawesi Selatan 90213. Populasi penelitian ini adalah seluruh karyawan di PT BNI Syariah Cabang Makassar sebanyak 67 karyawan. Adapun teknik pengambilan sampelnya menggunakan purposive sampling dengan penentuan kriteria pada sampel. Metode pengumpulan data dalam penelitian ini ada dua yaitu studi kepustakaan dan studi lapangan. Studi kepustakaan berupa jurnaljurnal publikasi, buku dan sebagainya dan studi lapangan pengumpulan data dengan menggunakan kuesioner. Metode analisis menggunakan analisis regresi linear berganda dan analisis regresi moderating dengan pendekatan uji selisih mutlak.

Metode analisis menggunakan regresi linear berganda yang dirumuskan sebagai berikut: 


$$
Y=\alpha+\beta_{1} X_{1}+\beta_{2} X_{2}+e
$$

Keterangan :

$$
\begin{array}{ll}
\mathrm{Y} & =\text { Kinerja Karyawan } \\
\mathrm{a} & =\text { Konstanta } \\
\mathrm{X}_{1} & =\text { Motivasi Kerja Perspektif Islam } \\
\mathrm{X}_{2} & =\text { Penggajian Perspektif Islam } \\
\beta_{1-} \beta_{2} & =\text { Koefisien regresi berganda } \\
\mathrm{e}=\text { error term }
\end{array}
$$

Metode analisis regresi moderating dengan pendekatan uji selisih mutlak yang dirumuskan sebagai berikut:

$$
\mathrm{Y}=\mathrm{\alpha}+\beta_{1} \mathrm{ZX} \mathrm{X}_{1}+\beta_{2} \mathrm{ZX} \mathrm{X}_{2}+\beta_{3}\left[\mathrm{ZX}_{1}-\mathrm{ZM}\right]+\beta_{4}\left[\mathrm{ZX}_{2}-\mathrm{ZM}\right]
$$

Keterangan :

$$
\begin{aligned}
& \mathrm{Y}=\text { Kinerja Karyawan } \\
& Z_{1} \quad=\text { Standardize Motivasi Kerja Perspektif Islam } \\
& \mathrm{ZX}_{2}=\text { Standardize Penggajian Perspektif Islam } \\
& \mathrm{ZM}=\text { Standardize Kepuasan Kerja } \\
& {\left[Z X_{1}-Z M\right]=\text { interaksi yang diukur dengan nilai absolut perbedaan antara } Z X_{1}} \\
& \text { dan ZM } \\
& {\left[\mathrm{ZX}_{2}-\mathrm{ZM}\right]=\text { interaksi yang diukur dengan nilai absolut perbedaan antara } Z \mathrm{X}_{2}} \\
& \text { dan ZM } \\
& \mathrm{a} \quad=\text { Kontanta } \\
& \beta \quad=\text { Koefisien Regresi } \\
& \text { e } \quad=\text { Error Term }
\end{aligned}
$$

Motivasi Kerja Perspektif Islam (X1): Motivasi kerja Islam adalah komitmen terkait pekerjaan yang berasal dari hubungan seorang karyawan dengan tuhannya (Rahman, 1995). Indikator: Niat baik dan benar, taqwa dalam bekerja, dan ihlas dalam bekerja (diukur dengan skala likert).

Penggajian Perspektif Islam (X2): Sistem penggajian adalah sistem yang digunakan oleh perusahaan untuk memberikan upah dan gaji kepada karyawannya atas jasa-jasa yang mereka berikan kepada perusahaan (Jiwandono dkk, 2017). Indikator: Pemisahan fungsi, pencatatan atau dokumentasi yang memadai, dan otorisasi (diukur dengan skala likert).

Kinerja Karyawan (Y): Kinerja adalah hasil kerja syarat kualitas dan kuantitas yang dicapai oleh seorang karyawan dalam melaksanakan tugasnya sesuai dengan tanggung jawab yang diberikan kepadanya (Mangkunegara, 2002:67). Indikator: Kuantitas hasil kerja, kualitas hasil kerja, dan kecepatan hasil kerja (diukur dengan skala likert).

Kepuasan Kerja (M): Kepuasan kerja merupakan seperangkat perasaan karyawan tentang menyenangkan atau tidaknya pekerjaan mereka (Urbayani, 2012). Indikator: Kepuasan kerja terhadap pekerjan itu sendiri, kepuasan terhadap promosi, dan kepuasan kerja terhadap atasan (diukur dengan skala likert). 


\section{PEMBAHASAN}

Penelitian ini dilakukan pada PT BNI Syariah Cabang Makassar. Proses pengumpulan data dilakukan dengan menyebarkan kuesioner langsung kepada responden yaitu karyawan PT BNI Syariah Cabang Makassar. Jumlah kuesioner yang disebarkan sebanyak 40 kuesioner namun yang dapat diolah sebanyak 30 kuesioner. Responden dalam penelitian ini adalah karyawan PT BNI Syariah Cabang Makassar. Sebanyak 30 responden yang terdiri dari 17 responden laki-laki dan 13 responden perempuan.

Analisis regresi digunakan untuk memprediksi pengaruh lebih dari satu variabel bebas terhadap satu variabel terikat, baik secara parsial maupun simultan, serta menguji hipotesis penelitian yang telah ditetapkan sebelumnya.

Hasil pengujian regresi linear berganda untuk hipotesis 1 dan 2 disajikan sebagai berikut:

Tabel 1. Hasil Uji Determinasi

\begin{tabular}{lrrrr}
\hline Model & $\mathrm{R}$ & R Square & $\begin{array}{c}\text { Adjusted R } \\
\text { Square }\end{array}$ & $\begin{array}{c}\text { Std. Error of the } \\
\text { Estimate }\end{array}$ \\
\hline 1 &, $722^{\mathrm{a}}$ &, 522 &, 486 & 2,69194 \\
\hline
\end{tabular}

a. Predictors: (Constant), Penggajian, Motivasi Kerja

Sumber: Output SPSS 21 (2018)

Berdasarkan tabel diatas diperoleh angka R (koefisien korelasi) sebesar 0,722. Hal ini menunjukkan terjadi hubungan positif yang cukup kuat antara motivasi kerja perspektif Islam dan penggajian perspektif Islam terhadap kinerja karyawan. Hasil analisis koefisien determinasi (R) menunjukkan bahwa persentase sumbangan pengaruh variabel independen (motivasi kerja perspektif Islam dan penggajian perspektif Islam) terhadap variabel dependen (kinerja karyawan) adalah sebesar $52,5 \%$. Sedangkan sisanya sebesar $47,8 \%$ dipengaruhi oleh variabel lain yang tidak dimasukkan atau tidak dibahas dalam penelitian ini.

\section{Hasil Uji Simultan (Uji F)}

Uji simultan atau uji F dilakukan untuk menguji signifikansi motivasi kerja perspektif Islam dan penggajian perspektif Islam terhadap variabel kinerja karyawan. Uji F dilakukan dengan membandingkan F-hitung dengan F-tabel. Tabel di bawah ini menunjukkan nilai F hitung sebesar 14,734 sedangkan nilai F-tabel pada tabel distribusi dengan tingkat probability 5\% adalah sebesar 3,35. Hal ini berarti F-hitung lebih besar dari pada F table $(14,734>3,35)$. 
Tabel 2. Hasil Uji Simultan

\begin{tabular}{llccccc}
\hline Model & & $\begin{array}{c}\text { Sum of } \\
\text { Squares }\end{array}$ & Df & $\begin{array}{c}\text { Mean } \\
\text { Square }\end{array}$ & F & Sig. \\
\hline \multirow{2}{*}{1} & Regression & 213,544 & 2 & 106,772 & 14,734 & \multirow{2}{*}{$000^{\mathrm{b}}$} \\
& Residual & 195,656 & 27 & 7,247 & & \\
& Total & 409,200 & 29 & & & \\
\hline
\end{tabular}

a. Dependent Variable: Kinerja Karyawan

b. Predictors: (Constant), Penggajian, Motivasi Kerja

Sumber: Output SPSS 21 (2018)

Berdasarkan tabel di atas menunjukkan bahwa tingkat signifikansi lebih kecil dari 0,05 maka diterima, sehingga dapat dikatakan bahwa motivasi kerja perspektif Islam dan penggajian perspektif Islam secara simultan (bersama-sama) mempunyai pengaruh terhadap kinerja karyawan, dengan probabilitas 0,000. Karena probabilitas jauh lebih kecil dari nilai signifikan 0,05, maka model regresi dapat digunakan untuk memprediksi tingkat kinerja karyawan.

\section{Hasil Uji Regresi Berganda}

Tabel 3 Hasil Uji Regresi Berganda

\begin{tabular}{|c|c|c|c|c|c|c|}
\hline & \multirow[t]{2}{*}{ Model } & \multicolumn{2}{|c|}{$\begin{array}{c}\text { Unstandardized } \\
\text { Coefficients }\end{array}$} & \multirow{2}{*}{$\begin{array}{c}\begin{array}{c}\text { Standardized } \\
\text { Coefficients }\end{array} \\
\text { Beta }\end{array}$} & \multirow[t]{2}{*}{$\mathrm{t}$} & \multirow[t]{2}{*}{ Sig. } \\
\hline & & $\mathrm{B}$ & Std. Error & & & \\
\hline \multirow{3}{*}{1} & (Constant) & 3,451 & 5,036 & & 685 & 499 \\
\hline & $\begin{array}{l}\text { Motivasi } \\
\text { Keria }\end{array}$ & ,475 & 158 & , 450 & 3,002 & ,006 \\
\hline & Penggajian & ,325 & 123 & ,395 & 2,638 & ,014 \\
\hline
\end{tabular}

a. Dependent Variable: Kinerja Karyawan

Sumber: Output SPSS 21 (2018)

Berdasarkan analisis regresi linear berganda diperoleh persamaan regresi sebagai berikut:

$$
\mathrm{Y}=3,451+475 \mathrm{X} 1+325 \mathrm{X} 2+\mathrm{e}
$$

Hasil pengujian regresi moderasi dengan pendekatan uji selisih mutlak untuk hipotesis penelitian 3 dan 4 disajikan sebagai berikut: 


\section{Hasil Uji Determinasi}

Tabel 4. Hasil Uji Determinasi

\begin{tabular}{lcccc}
\hline Model & $\mathrm{R}$ & $\mathrm{R}$ & $\begin{array}{c}\text { Adjusted R } \\
\text { Square }\end{array}$ & $\begin{array}{c}\text { Std. Error of the } \\
\text { Square }\end{array}$ \\
\hline 1 &, $804^{\mathrm{a}}$ &, 646 &, 572 & 2,45734 \\
\hline a. Predictors: (Constant), X2_M, Zscore: Kepuasan Kerja, \\
X1_M, Zscore: Penggajian, Zscore: Motivasi Kerja \\
Sumber: Output SPSS 20 (2018)
\end{tabular}

Berdasarkan tabel diatas diperoleh angka R (koefisien korelasi) sebesar 0,804. Hal ini menunjukkan terjadi hubungan yang cukup kuat antara motivasi kerja perspektif Islam dan Penggajian perspektif Islam terhadap kinerja karyawan. Hasil analisis koefisien determinasi (R) menunjukkan bahwa persentase sumbangan pengaruh variabel independen (motivasi kerja perspektif Islam dan penggajian perspektif Islam) terhadap variabel dependen (kinerja karyawan) yang dimoderasi oleh kepuasan kerja adalah sebesar 64,6\%. Sedangkan sisanya sebesar 35,4\% dipengaruhi oleh variabel lain yang tidak dimasukkan atau tidak dibahas dalam penelitian ini.

\section{Hasil Uji Simultan (Uji F)}

Uji simultan atau uji F dilakukan untuk menguji signifikansi kepuasan kerja dan salary terhadap variabel turnover intention karyawan. Uji F dilakukan dengan membandingkan F-hitung dengan F-tabel. Tabel di bawah ini menunjukkan nilai $\mathrm{F}$ hitung sebesar 8,753 sedangkan nilai F-tabel pada tabel distribusi dengan tingkat probability $5 \%$ adalah sebesar 3,35. Hal ini berarti F-hitung lebih besar dari pada $\mathrm{F}$ table $(8,753>3,35)$.

Tabel 5 Hasil Uji Simultan

\begin{tabular}{rlrrrrr}
\hline Model & & $\begin{array}{c}\text { Sum of } \\
\text { Squares }\end{array}$ & Df & Mean Square & F & Sig. \\
\hline \multirow{2}{*}{1} & Regression & 264,276 & 5 & 52,855 & 8,753 &, $000^{\mathrm{b}}$ \\
& Residual & 144,924 & 24 & 6,039 & & \\
& Total & 409,200 & 29 & & & \\
\hline
\end{tabular}

a. Dependent Variable: Kinerja Karyawan

b. Predictors: (Constant), X2_M, Zscore: Kepuasan Kerja, X1_M, Zscore:

Penggajian, Zscore: Motivasi Kerja

Sumber: Output SPSS 20 (2018)

Berdasarkan tabel di atas menunjukkan bahwa tingkat signifikansi lebih kecil dari 0,05 maka diterima, sehingga dapat dikatakan bahwa motivasi kerja perspektif Islam dan penggajian perspektif Islam dan kepuasan kerja secara simultan (bersamasama) mempunyai pengaruh terhadap kinerja karyawan, dengan probabilitas 0,000 . 
Karena probabilitas jauh lebih kecil dari nilai signifikan 0,05, maka model regresi moderasi dapat digunakan untuk memprediksi tingkat kinerja karyawan.

\section{Hasil Uji Regresi Moderasi (Pendekatan Selisih Mutlak)}

Tabel 6 Hasil Uji Regresi Moderasi

\begin{tabular}{|c|c|c|c|c|c|c|}
\hline \multirow{2}{*}{\multicolumn{2}{|c|}{ Model }} & \multicolumn{2}{|c|}{$\begin{array}{c}\text { Unstandardized } \\
\text { Coefficients }\end{array}$} & \multirow{2}{*}{$\begin{array}{c}\text { Standardized } \\
\text { Coefficients } \\
\text { Beta } \\
\end{array}$} & \multirow[t]{2}{*}{$\mathrm{t}$} & \multirow[t]{2}{*}{ Sig. } \\
\hline & & B & Std. Error & & & \\
\hline \multirow{7}{*}{1} & (Constant) & 28,357 & 1,026 & & 27,640 & ,000 \\
\hline & $\begin{array}{l}\text { Zscore: Motivasi } \\
\text { Kerja }\end{array}$ & ,958 & 624 & ,255 & 1,534 & 138 \\
\hline & Zscore: & 1,022 & ,567 & 272 & 1,804 & ,084 \\
\hline & Penggajian & & & & & \\
\hline & $\begin{array}{l}\text { Zscore: Kepuasan } \\
\text { Kerja }\end{array}$ & 1,239 & ,666 & ,330 & 1,858 & ,075 \\
\hline & X1_M & 2,150 & ,903 & 294 & 2,380 & ,026 \\
\hline & X2_M & 1,047 & ,824 & ,169 & 1,271 & ,216 \\
\hline
\end{tabular}

a. Dependent Variable: Kinerja Karyawan

Sumber: Output SPSS 20 (2018) berikut:

Berdasarkan analisis regresi moderasi diperoleh persamaan regresi sebagai

$$
Y=28,357+0,958 X_{1}+1,022 X_{2}+01,239 Z M+2,150\left[Z X_{1}-Z M\right]+1,047\left[Z X_{2}-Z M\right]
$$

\section{Pengaruh Motivasi Kerja Perspektif Islam Terhadap Kinerja Karyawan PT BNI Syariah Cabang Makassar}

Hasil uji berdasarkan hasil uji hipotesis, menunjukkan bahwa variabel motivasi kerja perspektif Islam berpengaruh positif dan signifikan terhadap kinerja karyawan. seperti yang diketahui semakin baik motivasi kerja yang diberikan oleh PT BNI Syariah Cabang Makassar kepada karyawan makan akan semakin mendorong semangat dan tanggungjawab karyawan untuk meningkatkan kinerjanya.

Hasil penelitian ini sejalan dengan Theory Planned Behavior (TPB) yang dikemukakan oleh Ajzen 1958 menjelaskan bahwa perilaku seseorang atau individu timbul karena adanya niat untuk berprilaku. Dengan demikian, karyawan yang sering diberikan motivasi kerja sesuai syariat Islam akan cenderung untuk melaksanakan tugas dan tanggungjawabnya dengan sepenuh hati untuk mewujudkan tujuan perusahaan. Hasil penelitian ini memperkuat hasil penelitian Anoraga (2015), Supatmi dkk (2012), dan Murty dan Hudiwinarsih (2013) yang menyatakan kinerja karyawan dapat ditingkatkan dengan memberikan motivasi kerja, Karyawan yang memiliki motivasi kerja yang tinggi terhadap pekerjaannya cenderung akan bertahan dalam organisasi, dan memberikan kinerja yang baik untuk 
perusahaan. Hal ini tidak sejalan dengan penelitian Sverke dkk (2002) dan Artiningrum dan Satrya (2016) menyatakan bahwa motivasi kerja perspektif Islam bukan satu-satunya yang menjadi tolak ukur karyawan meningkatkan kinernya, selain kepuasan kerja, ada beberapa faktor yang juga dapat meningkatkan kinerja karyawan seperti career management, training satisfaction, pay satisfaction. Dengan menerapkan beberapa faktor tersebut juga akan meningkatkan kinerja dan komitmen karyawan terhadap PT BNI Syariah Cabang Makassar.

\section{Pengaruh Penggajian Perspektif Islam Terhadap Kinerja Karyawan PT BNI Syariah Cabang Makassar .}

Hasil uji berdasarkan hasil uji hipotesis, menunjukkan bahwa variabel penggajian perspektif Islam berpengaruh positif dan signifikan terhadap kinerja karyawan. Seperti yang diketahui semakin baik sistem pengajian yang diterapkan PT BNI Syariah Cabang Makassar kepada karyawan maka akan semakin mendorong semangat untuk meningkatkan kinerjanya dan meningkatkan kepercayaan karyawan terhadap perusahaan.

Hasil penelitian ini menunjukkan bahwa penggajian perspektif Islam berpengaruh positif terhadap kinerja karyawan. Semakin bagus sistem pengajian yang diberian oleh PT BNI Syariah Cabang Makassar akan semakin kuat komitmen yang dimiliki karyawan maka semakin kuat pula untuk meningkatkan kinerjanya. Semakin tinggi tingkat kepuasan atas gaji yang dirasakan oleh karyawan maka akan menurunkan sikap acuh karyawan terhadap pekerjaan yang berdampak pada kinerja perusahaan. Hal tersebut sejalan dengan teori keadilan yang didasarkan pada asumsi bahwa orang-orang dimotivasi oleh keinginan untuk diperlakukan secara adil dalam pekerjaannya. Setiap individu mengharapkan bahwa mereka akan mendapatkan pertukaran usaha dan imbalan secara adil dari organisasi. Hasil penelitian ini memperkuat penelitian Dhermawan dkk (2012), Juniantara dan Riana (2015), dan Suwati (2013) yang menyatakan bahwa sistem penggajian yang baik dapat mendorong gairah kerja dan keinginan karyawan untuk mencapai prestasi kerja yang optimal sehingga membantu terwujudnya sasaran perusahaan. Namun lain halnya dengan penelitian Juhdi dkk (2013) menyatakan bahwa pelatihan merupakan salah satu cara untuk meningkatkan komitmen organisasi dan meningkatkan kinerja karyawan terhadap organisasi tempatnya bekerja.

\section{Pengaruh Kepuasan Kerja dalam Memoderasi Motivasi Kerja Perspektif Islam Terhadap Kinerja Karyawan}

Berdasarkan hasil regresi pendekatan uji selisih mutlak menunjukkan bahwa variabel koefisien beta unstandardized sebesar 2,150 dan tingkat signifikansi 0,026 yang lebih kecil dari 0,05. Kepuasan kerja dianggap variabel moderating apabila tingkat signifikannya lebih kecih dari 0,05, maka $\mathrm{H}_{3}$ diterima. Hal ini membuktikan bahwa PT BNI Syariah Cabang Makassar yang memberikan motivasi kerja perspektif Islam terhadap karyawannya akan meningkatkan kinerja setiap karyawan, karena karyawan yang memiliki motivasi kerja perspektif Islam dapat memberikan kepribadian yang baik dan dibenarkan oleh Islam, sehingga motivasi kerja perspektif Islam yang di dorong dengan adanya kepuasan kerja yang tinggi akan menunjukkan 
perilaku dan kinerja yang berkualitas sehingga dapat mencapai tujuan dari PT BNI Syariah Cabang Makassar.

Motivasi kerja perspektif Islam yang diberikan PT BNI Syariah Cabang Makassar yang diikuti oleh kepuasan kerja, akan mendorong seorang karyawan untuk tetap tinggal pada organisasi tersebut dan terus meningkatkan kualitas kinerjanya. Kepuasan kerja mempunyai peran penting dalam rangka mendukung tercapainya tujuan sebuah perusahaan (Sidarta dan Margaretha, 2011). Namun apabila motivasi kerja tidak di dukung dengan adanya kepuasan kerja karyawan tidak akan memberikan perubahan pada karyawan untuk meningkatkan kinerjanya terhadap perusahaan, karena merasa tidak diberikan hak dan kebutuhannya terutama dalam hal kepuasan kerja. Oleh karena itu, motivasi kerja perspektif Islam yang didukung dengan kepuasan kerja akan lebih efektif dalam peningkatan kinerja suatu organisasi karena dapat memberikan semangat dan gairah kepada karyawan untuk terus meningkatkan kualitas kinerjanya terhadap perusahaan.

\section{Pengaruh Kepuasan Kerja dalam Memoderasi Penggajian Terhadap Kinerja Karyawan}

Berdasarkan hasil regresi pendekatan uji selisih mutlak menunjukkan bahwa variabel koefisien beta unstandardized sebesar 1,047 dan tingkat signifikansi 0,216 lebih besar dari 0,05. Kepuasan kerja dianggap variabel moderating apabila tingkat signifiannya lebih kecil dari 0,05, maka $\mathrm{H}_{4}$ ditolak. Hal ini membuktikan bahwa sistem penggajian perspektif Islam yang diterapkan PT BNI Syariah Cabang Makassar dalam pemberian gaji karyawan mampu memberikan kepuasan terhadap karyawan sehingga dapat meningkatkan kinerjanya. Karyawan yang merasa puas atas gaji yang didapatkan dari suatu organisasi atau perusahaan baik dalam jumlah yang diterima dan prosedur pembayaran gaji yang diberikan, karyawan akan cenderung untuk bekerja lebih giat dan meningkatkan kinerjanya karena merasa kinerjanya telah sesuai dengan imbalan yang diterima, tanpa harus didukung dengan kepuasan kerja karyawan dengan sendirinya akan merasa puas apabila sistem penggajian yang diterapkan PT BNI Syariah Cabang Makassar sesuai dengan syariat Islam.

Sistem penggajian yang baik sesuai dengan syariat Islam yang diberikan perusahaan kepada seluruh karyawan akan menumbuhkan kepercayaan karyawan terhadap perusahaan. Kepuasan gaji dapat diartikan bahwa seseorang akan terpuaskan dengan gajinya ketika persepsi terhadap gaji dan apa yang mereka peroleh sesuai dengan yang diharapkan. Beberapa penelitian mengidentifikasi aspek kepuasan yang ditemukan berhubungan dengan keinginan individu untuk meninggalkan organisasi meliputi kepuasan akan upah dan promosi (Wahyu dan Muna, 2012). Faktor utama pendorong niat sesesorang untuk pindah tempat kerja terutama dipengaruhi oleh kepuasaan karyawan terhadap gaji, tunjangan, dan kompensasi lainnya yang ditawarkan oleh perusahaan. Namun, jika karyawan merasakan kepuasan terhadap gaji yang diberikan dan sistem penggajian yang diterapkan oleh perusahaan dapat dipercaya, maka karyawan akan lebih cenderung untuk meningkatkan kinerjanya terhadap perusahaan. 


\section{PENUTUP}

Penelitian ini mengenai pengaruh kepuasan kerja dalam memoderasi motivasi kerja perspektif Islam dan penggajian perspektif Islam terhadap kinerja karyawan PT BNI Syariah Cabang Makassar menghasilkan kesimpulan yang didasarkan pada analisis bahwa motivasi kerja perspektif Islam dan penggajian perspektif Islam memberikan pengaruh positif terhadap kinerja karyawan pada PT. BNI Syariah Cabang Makassar, dan kepuasan kerja mampu memoderasi hubungan positif motivasi kerja perspektif Islam terhadap kinerja karyawan, namun tidak mampu memoderasi penggajian perspektif Islam terhadap kinerja karyawan PT BNI Cabang Makassar.

Penelitian ini merekomendasikan bagi instansi diharapkan PT BNI Syariah Cabang Makassar meningkatkan kinerja karyawan dalam mencapai tujuan perusahaan melalui beberapa faktor, salah satunya dengan memberikan dan menciptakan motivasi kerja perspektif Islam dan penerapan sistem penggajian perspektif Islam dengan tujuan untuk lebih meningkatkan kinerja karyawan. Bagi peneliti selanjutnya disarankan untuk memperluas objek penelitian, selain PT BNI Syariah Cabang Makassar seperti dilakukan diInstansi BUMN lainnya atau Instansi Syariah. Selain itu disarankan bagi peneliti selanjutnya untuk mengembangkan penelitian ini dengan meneliti faktor-faktor lain yang lebih berpengaruh terhadap turnover intention karyawan.

\section{DAFTAR PUSTAKA}

Anoraga, Bhirawa, dan Ari Prasetyo. 2015. Motivasi Kerja Islam dan Etos Kerja Islam Karyawan Bank Jatim Syariah Cabang Surabaya. JESST. 2(7): 531-541.

Artiningrum, Budi dan Aryana Satrya. 2016. Analisis Pengaruh Career Management, Training Satisfaction, Pay Satisfaction Terhadap Turnover Intention dan Peran Mediasi Organizational Engagement Pada Karyawan Sektor Perbankan. Jurnal Manajemen dan Bisnis Sriwijaya. 14(3):337-352

Dhermawan, Anak Agung Ngurah Bagus, I Gde Adnyana Sudibya, dan I Wayan Mudiartha Utama. 2012. Pengaruh Motivasi, Lingkungan Kerja, Kompetensi dan Kompensasi Terhadap Kepuasan Kerja dan Kinerja Pegawai di Lingkungan Kantor Dinas Pekerjaan Umum Provinsi Bali. Jurnal Manajemen, Strategi Bisnis, dan Kewirausahaan. 6(2): 173-184.

Hersusdadikawati, Endang. 2005. Pengaruh Kepuasan Atas Gaji Terhadap Keinginan Untuk Berpindah Kerja dengan Komitmen Organisasional sebagai Variabel Intervening. Jurnal Studi Manajemen dan Organisasi, 2(1): 85-110.

Jaya, Indra. 2012. Pengaruh Kemampuan dan Motivasi Kerja Terhadap Kinerja Pegawai dinas Pendidikan Kabupaten Tanjung Jabung Barat. Jurnal Penelitian Universitas Jambi Seri Humaniora. 14(1): 37-46

Jiwandono, digo, Topojiwono, dan Fransisca Yaningwati. 2017. Analisis Sistem akuntansi Penggajian dan Pengupahan Dalam Rangka Mendukung Pengendalian Intern. Jurnal Administrasi Bisnis. 51(2): 1-10. 
Juhdi, N, Pa'wan, F dan Hansaram, R. M. 2013. HR practices and turnover intention: the mediating roles of organizational commitment and organizational engagement in a selected region in Malaysia. The International Journal of Human Resource Management, 24(15):3002-3019

Juniantara, I Wayan, dan I Gede Riana. 2015. Pengaruh Motivasi dan Kepuasan Kerja Terhadap Kinerja Karyawan Koperasi Di Denpasar. E-Jurnal Ekonomi dan Bisnis Universitas Udayana. 4(9): 611-629.

Kasenda, Ririvega. 2013. Kompensasi dan Motivasi Pengaruhnya Terhadap Kinerja Karyawan Pada PT Bangun Wenang Beverages Company Manado. Jurnal Emba 1(3): 853-859.

Koesmono, Teman. 2005. Pengaruh Budaya Organisasi terhadap Motivasi dan Kepuasan Kerja serta Kinerja Karyawan pada Sub Sektor Industri Pengolahan Kayu Skala Menengah di Jawa Timur. Jurnal Manajemen dan Kewirausahaan, 7(2):171-188.

Mangkunegara, Anwar P. 2002. Evaluasi Kinerja Sumber Daya manusia. Bandung: Refika Aditama..

Martoyo, Susilo. 2007. Manajemen Sumber Daya Manusia. Edisi Kelima. Yogyakarta: BPFE Yogyakarta.

Muljani, N. 2002. Kompensasi sebagai Motivator untuk Meningkatkan Kinerja Karyawan. Jurnal Manajemen dan Kewirausahaan , 4(2), 108-122.

Mulyanto dan Dyah Widayati. 2010. Pengaruh Kepemimpinan dan Motivasi Kerja Terhadap Kinerja Pegawai dengan Kepuasan Kerja sebagai Variabel Moderating. STIE AUB Surakarta. 1-21.

Murty, Harry, dan Veronika Agustini Srimulyani. 2013. Pengaruh Motivasi Terhadap Kinerja Pegawai dengan Variabel Pemediasi Kepuasan Kerja Pada PDAM Kota Madiun. Jurnal Riset Manajemen dan Akuntansi.1(1): 10-18.

Murty, Windi Aprilia, dan Gunasti Hudiwinarsih. 2016. Pengaruh Kompensasi, Motivasi, dan Komitmen Organisasional Terhadap Kinerja Karyawan Bagian Akuntansi. The Indonesian Akuntansi Review. 2(2): 215-228.

Nurdiana, Triyono. 2011. Pengaruh Rotasi Kerja dan KompensasiTerhadap Kinerja Pegawai: Kepuasan KerjaSebagai Variabel Intervening. Jurnal Ekonomi Manajemen Sumber Daya, 11(2):1-15.

Pratama, Riskiki Putrananta, Moch Dzulkiron AR, dan Zahro Z.A. 2016. Analisis Sistem Akuntansi Penggajian Dalam Rangka Meningkatkan Pengendalian Intern. Jurnal Administrasi Bisnis. 31(1): 118-123.

Rahman, Abdel AA. 1995. An Islamic Perspective on Organizational Motivation. The American Journal of Islamic Social Science. 12(2): 1-15.

Rangkuti, Afifa. 2017. Konsep Keadila dalam Perspektif Islam. Jurnal Pendidikan Islam.6(1):1-21. 
Rivai, Veithzal. 2009. Islam Human Capital dari teori dan praktik manajemen sumber dayamanusia. Edisi Pertama. Jakarta : Rajawali Pers.

Sanyata, Sigit. 2012. Teori dan Aplikasi Pendekatan Behavioristik dalam Konseling. Jurnal Paradigma, 14: 1-11.

Sidarta, Novita, dan Meily Margaretha. 2011. Dampak Komitmen Organisasi dan Kepuasan Kerja Terhadap Turnover Intention: Studi Empiris Pada Karyawan Bagian Operator di Salah Satu Perusahaan Garment Di Cimahi. Jurnal Manajemen. 10(2): 129-142.

Supatmi, Mamik Eko, Umar Nimran, dan Hamidah Nayati Utami. 2012. Pengaruh Pelatihan, Kompensasi Terhadap Kepuasan Kerja Karayawan dan Kinerja Karyawan. Jurnal Profit. 7(1): 25-36.

Suwati, Yuli. 2013. Pengaruh Kompensasi dan Motivasi Kerja Terhadap Kinerja Karyawan Pada PT Tunas Hijau Samarinda. Jurnal Administrasi Bisnis.1(1): 4155.

Sverke, M, Hellgren, J dan Naswall, K. 2002. No security: A meta-analysis andreview of job insecurity and its consequences. Journal of Occupational Health psychology, 7(3), 242-264.

Tiraada, Tryana. A.M. 2013. Kesadaran Perpajakan, Sanksi Pajak, Sikap Fiskus Terhadap Kepatuhan WPOP di Kabupaten Minahasa Selatan. Jurnal EMBA, 1(3): 999-1008Tindow, Mohammad Iman, Peggy A. Mekel dan Greis M. Sendow. 2014. Disiplin Kerja, Motivasi dan Kompensasi Pengaruhnya Terhadap Kinerja Karyawan Pada PT Bank Sulut Cabang Calaga. Jurnal EMBA. 2(2): 1594-1606.

Toly, Agus Arianto. 2001. Analisis Faktor-Faktor yang Mempengaruhi Turnover Intentions pada Staf Kantor Akuntan Publik. Jurnal Akuntansi dan Keuangan. 3(2): 102-125.

Wibowo. 2012. Manajemen Kinerja (Edisi Ke 3). Jakarta : Rajawali Pers

Wijaya, Tanto dan Fransisca Andreani. 2015. Pengaruh Motivasi dan Kompensasi Terhadap Kinerja Karyawan Pada PT Sinar Jaya Abadi Bersama. AGORA. 3(2):37-45.

Wijayanti, Ratna dan Meftahudin. 2016. Pengaruh Kepemimpinan Islami, Motivasi dan Kepuasan Kerja Terhadap Kinerja Karyawan dengan Lama Kerja sebagai Variabel Moderating. Jurnal PPKM III. 185-192. 